\title{
DESAIN BAHAN AJAR UNTUK PEMBELAJARAN BAHASA ARABMADRASAH IBTIDAIYAH
}

\author{
Husnan \\ Program Studi Bahasa Arab, Universitas Muhammadiyah Mataram, Indonesia \\ Husnanhanan4780@gmail.com
}

\begin{tabular}{l} 
INFO ARTIKEL \\
\hline Riwayat Artikel: \\
Diterima: $12-07-2019$ \\
Disetujui: $19-09-2019$
\end{tabular}

\section{Kata Kunci:}

Desain bahan ajar;

Pendekatan;

Kompone pembelajaran.

Keywords:
Design the teaching
materials;
Approach
Learning Kompone.

\section{A. LATAR BELAKANG}

Bahasa memiliki peran sentral dalam kehidupan manusia karena dengan bahasalah manusia dapat saling memahami hal-hal yang dimaksud. Ide dan pokok-pokok fikiran manuisa hanya akan dapat diekspresikan melalui bahasa sehingga orang lain akan memahami ide dan pokok fikiran tersebut. Agar memiliki bahasa yang baik dan benar maka bahasa harus dipelajari. Dengan mempelajari bahasa maka seseorang akan dapat berbahasa dan memahami setiap komunikasi dengan komprehensip.

Bahasa diperoleh pertama kali dengan cara mendengar. Bahkan diakui bahwa kemampuan berbahasa yang dimiliki setiap manusia tidak lain adalah dari aktivitas mendengarkan komunikasi ibu dan orang-orang terdekat dalam keluarga.

Mempelajari bahasa asing memiliki kesulitan dan kemudahan tergantung persamaan dan perbedaan

\section{ABSTRAK}

Abstrak: Merancang bahan ajar agar mudah dipahami oleh para siswa adalah bagian terpisahkan dari tugas seorang guru. Untuk itu guru harus memperkaya dir digunakan da proses pemb dan pendekatan ketika merancang bahan ajar. Pendekatan yang harus dipegang oleh erang guru ketika merancanga bahan ajar adalah pendekatan ilmu dan teknologi, baik maka setiap komponen pembelajaran mulai dari guru, siswa, materi, metode dan evaluasi harus memiliki memiliki porsi yang seimbang sehingga komonikasi dialogis

Abstract: Designing the teaching materials to be easily understood by the students is an integral part of a teacher's assignment. Therefore, teachers must enrich themselves with ariety of knowledge so that they can design teaching materials that are usable in the designing teaching materials. The approa that a teacher must hold when the teaching material is an approach to science and technology, a social culture approach and a psychological approach. In addition it should be considered that the absolute aurement for the learning process to run properly then every component of learning balanced portion so that the comsonity Dialogical will continue to create an atmosphere of a living class. yang dimiliki antara bahasa pertama dan bahasa kedua yang dipelajari. Semakin banyak persamaan yang dimiliki oleh bahasa pertama denagn bahasa kedua maka bahasa tersebut lebih mudah dan cepat dikuasai begitu juga sebaliknya.

Pembelajaran bahasa secara umum adalah proses perubahan tingkah laku melalui intraksi antar individu dan lingkungan agar memiliki kemampuan berbahasa. Proses merupakan rangkaian kegitan yang berkelanjutan, terencana, gradual, bergilir, berkesinambuangan dan terpadu yang secara keseluruhan mewarnai dan memberikan karakteristik terhadap proses pembelajaran. ${ }^{1}$ Untuk memenuhi semua unsur dalam proses pembelajaran maka setiap orang yang akan menyelenggarakan pembelajaran harus menyiapkan semua system pembelajaran yang

\footnotetext{
1 Iskandar Wasid dan Dadang Sunandar, Strategi Pembelajaran
} Bahasa, Bandung; PT Remaja Rosdakarya 2009. Hal.1 
dibutuhkan mulai dari; Guru, siswa, materi, metode dan evaluasi pembelajaran.

Pembelajaran bahasa asing secara khusus bahasa Arab pada setiap levelnya akan sangat berbeda dengan level lainnya. Bahasa arab untuk pemula akan dibedakan materi, metode dan evaluasi pembelajarannya dengan pembelajar untuk tingkat lanjutan. Untuk dapat menjalankan semua proses pembelajaran dengan efektif dan efesien maka perlu dilakukan rancangan materi ajar yang sesua dengan levelnya.

Materi ajar bahasa arab untuk Madrasah Ibtidaiyah harus didesain sebaik mungkin agar proses pembelajaran dikelas berjalan efektif. Perlu berbagai macam pertimbangan untuk diperhatikan agar materi tersebut memenuhi aspek kognitif, psikomotori dan afektif dari siswa madrasah ibtidaiyah. Untuk memenuhi ketiga domain tersebut maka dalam mendesai bahan ajar untuk siswa di madrasah Ibtidaiyah perlu mempertimbangkan berbagai pendekatan seperti pendekatan ilmu dan teknologi, sosial budaya dan psikologi.

Ketiga pendekatan tersebut sebagai jalan masuk untuk merencanakan penyusunan bahan ajar. Dengan pendekatan ilmu pengetahuan maka bahan ajar harus mengikuti perkembangan ilmu yang berbasis teknologi sehingga bahan ajar yang dihasilkan adalah yang terbaru. Dengan pendekatan social budaya maka bahan ajar harus mendekatkan para siswanya dengan realitas social dan budaya yang mereka miliki sehingga mereka akan cepat memahami sesuatu karena berangkat dari pengalaman langsung dari kehidupan mereka. Secara psikologi hendaknya bahan ajar itu ahrs disesuaikan dengan kemampuan para siswa dengan melihat kemampuan akal fikir dan umur mereka.

\section{B. PEMBAHASAN}

\section{1). Pengertian Desain Pembelajaran Bahasa Arab}

Desain bermakna adanya keseluruhan, struktur, kerangka atau outline, dan urutan atau sistematika kegiatan (Gagnon dan Collay, 2001). Selain itu, kata desain juga dapat diartikan sebagai proses perencanaan yang sistematika yang dilakukan sebelum tindakan pengembangan atau pelaksanaan sebuah kegiatan (Smith dan Ragan, 1993, p. 4). Sedangkan desain pembelajaran adalah kisi-kisi dari penerapan teori belajar dan pembalajaran untuk memfasilitasi proses belajar seseorang (Reigeluth, 1983). Desain pembelajaran juga diartikan sebagai proses merumuskan tujuan, strategi, teknik, dan media.
Di sisi lain Gagne mngembangkan konsep desain pembelajaran dengan menyatakan bahwa desian pembelajaran membantu proses belajar seseorang, dimana proses itu sendiri memiliki tahapan segera dan jangka panjang. Menurut mereka proses belajar terjadi karena adanya kondisi-kondisi belajar, internal maupun eksternal. Kondisi internal adalah kemampuan dan kesiapan diri pebelajar, sedangkan kondisi eksternal adalah pengaturan lingkungan yang didesain. Penyiapan kondisi eksternal belajar inilah yang disebut dengan desian pembelajaran. Untuk itu desain pembelajaran haruslah sistematis, dan menerapkan konsep pendekatan system agar berhasil meningkatkan mutu kinerja seseorang. Dan mereka berpendapat bahwa proses belajar yang terjadi secara internal dapat ditumbuhkan, diperkaya jika faktor eksernal, yaitu pembelajaran dapat didesain dengan efektif.

Desain pembelajaran lazimnya dimulai dari kegiatan analisis yang digunakan untuk menggambarkan masalah pembelajaran sesungguhnya yang perlu dicari solusinya. Setelah dapat menentukan masalah yang sesungguhnya maka langkah selanjutnya adalah menentukan alternaif solusi yang akan digunakan untuk mengatasi masalah pembelajaran. Seorang perancang program pembelajaran perlu menentukan solusi yang tepat dari berbagai alternatif yang ada. Selanjutnya ia dapat menerapkan solusi tersebut untuk mengatasi masalah yang dihadapi. Evaluasi adalah langkah selanjutnya, sehingga nantinya bias mengetahui rancangan atau desain yang sesuai dengan pembelajaran dan desain tersebut busa diaplikasikan dalam proses pembelajaran.

Secara garis besar desain pembelajaran Bahasa Arab terdiri dari lima langkah penting, yaitu: a), Analisis lingkungan dan kebutuhan belajar siswa. b),Merancang spesifikasi proses pembelajaran yang efektif dan efesien serta sesuai dengan lingkungan dan kebutuhan belajar siswa. c),Mengembangkan bahan-bahan untuk digunakan dalam kegiatan pembelajaran.d),Implementasi desain pembelajaran. e), Implementasi evaluasi formaif dan sumatif terhadap program pembelajaran

\section{2). Komponen Desain Pembelajaran Bahasa Arab}

Esensi desain pembelajaran hanyalah mencakup empat komponen, yaitu :

\section{a). Peserta Didik}

Dalam menentukan desain pembelajaran dan mata pelajaran yang akan disampaikan perlu diketahui bahwa yang sebenarnya dilakukan oleh para desainer adalah menciptakan situasi belajar 
yang kondusif sehingga tujuan pembelajaran dapat tercapai dan peserta didik merasa nyaman dan termotivasi dalam proses belajarnya.

Peserta didik sebelum dan selama belajar dapat dipengaruhi oleh berbagai factor baik fisik maupun mental, misalnya kelelahan, mengantuk, bosan, dan jenuh. Hal ini akan mengurangi kosentrasi peserta didik dan sudah tentu akan terjadi reduksi dalam penyerapan materi yang juga mempengaruhi daya tangkap untuk memahami materi.Hal-hal lain yang dapat mempengaruhi mutu belajar peserta didik adalah tampilan materi ajar dan gaya penyampaian guru dalam menyampaikan materi.

b). Tujuan

Setiap rumusan tujuan pembelajaran selalu dikembangkan berdasarkan kompetesi atau kinerja yang harus dimiliki oleh peserta didik jika ia selesai belajar. Seandainya tujuan pembelajaran atau kompetensi dinilai sebagai sesuatu yang rumit, maka tujuan pembelajaran tersebut dirinci menjadi subkompetensi yang dapat mudah dicapai. Dilain pihak desain pembelajaran memadukan kebutuhan peserta didik dengan kompetensi yang harus dikuasai dengan persyaratan tertentu dalam kondisi yang sudah ditetapkan. Pada situasi seperti ini seorang prancang pembelajaran dituntut piawai dalam memadukan kompetensi yang di harus dicapai dengan kondisi nyata dari lingkungan belajar yang dihadapi.

\section{c). Metode}

Metode terkait dengan strategi pembelajaran yang dirancang agar proses belajar berjalan baik dan lancar. Metode adalah cara-cara atau teknik yang dianggap jitu untuk menyampaikan materi ajar. Dalam desain pembelajaran langkah ini sangat penting karena metode dapat menentukan situasi belajar yang sesungguhnya. Di lain pihak kepiawaian seorang desainer pembelajaran juga terlihat dalam cara menentukan metode. Menciptakan situasi dan suasana belajar yang kodusif, tetap hidup ditentukan juga oleh penggunaan metode yang dipraktikkan.Pada konsep ini metode adalah komponen strategi pembelajaran yang diaplikasikan untuk mempermudah proses pembelajaran ketika guru menyampaikan materi di kelas.

\section{d). Evaluasi}

Konsep ini menganggap menilai hasil belajar peserta didik sangat penting. Indikator keberhasilan pencapaian suatu tujuan belajar dapat diamati dari penilaian hasil belajar. Seringkali penilaian dilakukan dengan cara menjawab soal-soal objektif. Penilaian juga dapat dilakukan dengan format non soal, yaitu dengan instrument pengamatan, wawancara, kuesioner dan sebagainya. Melakukan evaluasi terhadap proses pembelajaran dan desain pembelajaran yang telah dirancang adalah langkah pasti, karena evaluasi merupakan alat ukur yang paling layak untuk menilai hasil dari keseluruhan pembelajaran. 3). Sifat Desain Pembelajaran Bahasa Arab

a). Berorientasi pada peserta didik

Desain pembelajaran memang mengacu pada peserta didik. Setiap individu peserta didik dipertimbangkan memiliki kekhasan masingmasing. Menurut Smaldino, et al (edisi 8, 2005) setiap peserta didik memiliki perbedaan karena:

b). Karakteristik umum

Sifat internal yang mempengaruhi penyampaian materi seperti kemampuan membaca, jenjang pendidikan, usia, atau latar belakang social.

c). Kemampuan awal atau prasyarat

Kemampuan dasar yang harus dimiliki peserta didik sebelum peserta didik mempelajari kemampuan baru. Jika kemampuan awal ini kurang maka sebenarnya yang menjadi mata rantai penguasaan materi dan menjadi penghambat bagi proses belajar

\section{d). Gaya belajar}

Gaya belajar ini merupakan berbagai aspek psikologis yang mempengaruhi dan berdampak pada penguasaan kemampuan atau kompetensi. Cara mempersepsikan sesuatu hal, motivasi, kepercayaan diri, tipe belajar (verbal, visual, kombinasi dan sebagainya)

1). Alur berfikir Sistemik

Konsep sistem dan pendekatan system diterapkan secara optimal dalam desain pembelajaran sebagai kerangka berfikir. Sistem sebagai rangkaian komponen dengan masingmasing fungsi yang berbeda, bekerja sama dan berkordinasi dalam melaksanakan suatu tujuan yang telah dirumuskan. Rumusan ini menunjukkan bahwa kegiatan belajar mengajar jika diuraikan terjadi seperti sebagai suatu sistem. Keberhasilan atau kegagalan dalam pelaksanaannya dapat disebabkan oleh salah satu kompenen saja. Jadi jika ada perbaikan maka seluruh komponen harus ditinjau kembali.

2). Empiris dan Berulang

Setiap model desain pembelajaran bersifat empiris. Model apapun yang diajukan oleh pakar telah melalui kajian teori dan serangkaian uji coba yang mereka lakukan sendiri sebelum dipublikasikan. Pada pelaksanaannya, pengguna dapat menerapkan dan memperbaiki setiap tahap berulang kali sesuai dengan masukan demi untuk efektifitas pembelajaran. 


\section{4). Komponen Materi Ajar Pembelajaran Bahasa Arab}

Ada tiga komponen utama bahan ajar yaitu: 1),komponen utama, yang mencakup informasi atau topik utama yang ingin disampaikan kepada siswa, atau yang harus dikuasai siswa. 2), komponen pelengkap, yang mencakup informasi atau topik tambahan yang terintegrasi dengan bahan ajar utama, atau topik pengayaan wawasan siswa, seperti materi pengayaan, bacaan tambahan, jadwal, silabus dan bahan pendukung non cetak lainnya, dan 3), komponen evaluasi hasil belajar, yang mencakup tes dan non tes yang dapat digunakan untuk tes formatif dan sumatif siswa selama proses pembelajaran Bahasa Arab.

Bahan ajar juga harus memenuhi beberapa komponen yang relevan dengan kebutuhan proses pembelajaran, seperti: a).petunjuk penggunaan buku ajar, b).standar kompetensi dan kompetensi dasar, c).epitome/kerangka isi, d).uraian isi bahan pembelajaran, e).ilustrasi/gambar yang relevan, f).rangkuman, g).soal-soal latihan, kunci jawaban, h) feedback, dan i).tugas-tugas, baik yang bersifat individual maupun kelompok.

Untuk lebih memotivasi dan mempermudah siswa dalam mempelajari dan memahami isi bahan ajar, maka dalam bahan ajar itu harus tersedia:

a. petunjuk yang mampu menyajikan langkahlangkah yang mudah untuk memahami dan mengikuti setiap proses pembelajaran sesuai dengan materi yang disajikan

b. setiap materi yang disajikan harus terlebih dahulu dijelaskan tujuan pembelajaran yang ingin dicapai, dengan maksud untuk mengetahui tingkat pencapaian siswa terhadap materi yang dipelajari.

c. untuk menunjang penyajian materi perlu disajikan map atau bisa juga kerangka isi dalam bentuk diagram agar mahasiswa dapat mengetahui dan memahami bagian-bagian yang mencakup pokok bahasan dan sekaligus dapat melihat hubungan masing-masing bagian dalam pokok bahasan tersebut.

d. penyajian materi dari pokok bahasan sampai ke sub pokok bahasan diuraikan pada bagian ini secara jelas dan dibantu dengan gambar/ilustrasi atau bentuk lanilla.

\section{5). Materi Ajar Madrash Ibtida'iyah (MI)}

Kesuksesan pembelajaran tidak terlepas dari teknik-teknik pembelajran yang digunakan oleh guru. Oleh karena itu, guru seyogianya mengembangkan suatu teknik pembelajran yang tepat dengan kondisi anak didik.

Dalam pengembangan materi ajar di tingakt madrasah ibtida'iyah ada beberpa keterampilan yang dikembangakan seperti bahan ajar untuk madrash ibtida'iayah kelas 5 yaitu :

1. Mufradat

Dalam mufradat, kegiatan siswa adalah menghafalkan kosa kata yang disediakan. Banyak sedikitnya kosa kata yang dikuasai oleh siswa sangat menentukan berhasil tidakanya penguasaan materi pelajaran secara keseluruhan. Langkahlangkah yang dapat ditempuh adalah sebagai berikut:a),Guru mengucapkan mufradat satu persatu dengan lafal dan intonasi yang benar sebagai contoh bagi siswa.dengan demikian, siswa diharapkan tidak melakukan kesalhan dalam pengucapan sebab pengucapan huruf yang salah akan mengubah arti suatu kata. b),Untuk memperjelas makna kata yang bersangkutan, guru dapat menggunakan model, sampel, gambar, atau peragaan. c).Kegiatan menghafal dapat dilakukan siswa, baik disekolah maupun dirumah. Cara mengahafal yang dapat ditempuh adalah dengan mengulang-ulang mulai dari nomor pertama. Kemudian diteruskan pada nomor dua dan seterusnya.setelah dirasa hafal, buku ditutup dan cobalah mengulang tanpa membuka buku.

Contoh mufradat:

\begin{tabular}{|c|c|}
\hline J. Rumah & Kيت ج بيوت \\
\hline L. Pintu & M. باب ج أبواب \\
\hline N. Jendela & OLاقذة ج نوافذ \\
\hline P. Ruangan makan & غرفة لأكل . \\
\hline
\end{tabular}

2. Istima'

3. Muhadasah

4. Qira'ah

5. kitabah

Salah satu prinsip linguistik menyatakan bahwa bahasa itu pertama-tama adalah ujaran, yakni bunyi-bunyi bahasa yang diucapkan dan bisa didengar. Atas dasar itulah beberapa ahli pengajaran bahasa menetapkansatu prinsip bahwa pengajaran bahasa harus dimulai dengan mengajarkan aspek-aspek pendengaran dan pengucapan sebelum membaca dan menulis.

Dengan demikian, menyimak merupakan satu pengalaman belajar yang amat penting bagi para siswa dan seyogyanya mendapat perhatian sungguh-sungguh dari pengajar. Implikasinya dalam pelaksanaan pengajaran ialah bahwa guru hendaknya memulai pelajarannya dengan memperdengarkan (sebaiknya secara spontan, tidak dengan membaca) ujaran-ujaran Bahasa Arab baik berupa kata-kata maupun kalimat, setidak-tidaknya ketika guru memperkenalkan kata-kata baru, ungkapan-ungkapan baru, atau 
pola kalimat baru. Manfaat dan aktifitas ini ialah untuk membiasakan murid mendengar ujaran dan mengenal dengan baik tata bunyi Bahasa Arab, disamping dapat menciptakan kondisi belajar penuh gairah dan menumbuhkan motivasi dalam diri murid. Hal ini sengaja ditekankan di sini, karena berdasar pengamatan, banyak di antara guru Bahasa Arab yang cenderung mengajak murid-muridnya membaca buku teks sejak awal pelajaran.

Secara umum tujuan latihan menyimak adalah agar siswa dapat memahami ujaran dalam Bahasa Arab, baik bahasa sahari-hari maupun bahasa yang digunakan dalam forum resmi.

\section{6). Tahap Latihan Menyimak}

a). Latihan pengenalan (identifikasi)

Kemahiran menyimak (istima') pada tahap pertama bertujuan agar siswa dapat mengidentifikasi bunyi-bunyi Bahasa Arab secara tepat. Latihan pengenalan ini sangat penting karena sistem tata bunyi Bahasa Arab banyak berbeda dengan bahasa Indonesia dan bahasa daerah yang dikenal oleh siswa. Satu keuntungan bagi guru Bahasa Arab bahwa umumnya anak-anak Indonesia khususnya yang muslim telah mengenal bunyi-bunyi Bahasa Arab sejak masa kanak-kanak, dengan adanya pelajaran membaca Al-Quran dan shalat. Namun ini tidak mengurangi pentingnya latihan tersebut, karena ternyata pengenalan mereka itu belum tuntas. Ada bunyi bahas Arab yang sama dengan bunyi bahasa pelajar, ada yang mirip dan ada yang sama sekali tidak dikenal (asing). Berdasarkan kenyataan ini, guru harus memberikan perhatian khusus kepada bunyi-bunyi yang mirip dan yang asing sama sekali bagi pelajar. Contoh : أليم dengan

\section{b). Latihan mendengarkan dan menirukan}

Walaupun latihan-latihan menyimak bertujuan melatih pendengaran, tapi dalam praktek selalu diikuti dengan latihai pengucapan dan pemahaman, bahkan yang disebut terakhir inilal: yang manjadi rujuan akhir dari latihan menyimak. Jadi setelah siswa mengenal bunyi-bunyi Bahasa Arab melalui ujaran-ujaran yang didengarnya, ia kemudian dilatih untuk mengucapkan dan mamahami makna yang dikandung oleh ujaran tersebut. Dengan demikian pelajaran isrima'sekaligus melatih kemampuan reseptif dan produktif.

Dalam tahap permulaan, siswa dilatih untuk mendengarkan dan menirukan. Kegiatan ini dilakukan oleh guru, ketika memperkenajkan katakata atau pola kalimat yang baru, atau dalam waktu yang sengaja dikhususkan untuk latihan menyimak. Latihan menirukan ini difokuskan pada bunyi-bunyi bahasa yang asing bagi siswa, juga pada pengucapan vokal panjang dan pendek, bertasydid dan tidak bertasydid, yang tidak dikenal dalam bahasa Indonesia.

c). Latihan mendengarkan dan memahami

Tahap selanjutnya, setelah siswa mengenal bunyi-bunyi bahasa dan dapat mengucapkannya, latihan menyimak bertujuan agar siswa mampu memahami bentuk dan makna dari apa yang didengarnya itu. Latihan mendengar untuk pemahaman ini dapat dilakukan dengan berbagai macam teknik, antara lain:

1) latihan melihat dan mendengar (انظر واسمع)

Guru memperdengarkan materi yang sudah direkam, dan pada waktu yang sama memperlihatkan rangkaian gambar yang mencerminkan arti dan isi materi yang didengar oleh siswa tadi. Gambar-gambar tersebut bisa berupa film-strip, slide, gambar dinding dan sebagainya.

2) Latihan membaca dan mendengar (اقرأو اسمع)

Guru memperdengarkan materi bacaan yang sudah direkam dan siswa membaca teks (dalam hati) mengikuti materi yang diperdengarkan. Pada tingkat permulaan, perbendaharaan kata-kata yang dimiliki siswa masih terbatas. Oleh karena itu, harus dipilihkan bahan yang pendek-pendek, mungkin berupa percakapan sehari-hari atau ungkapan-ungkapan sederhana yang tidak terlalu kompleks.

3) Latihan mendengarkan dan memeragakan ( اقرأ (ومثّل

Dalam latihan ini, siswa diminta melakukan gerakan atau tindakan non verbal sebagai jawaban terhadap stimulus yang diperdengarkan oleh guru. Kegiatan ini tidak terbatas pada ungkapan seharihari digunakan oleh guru dalam kelas seperti: اقر أ ـ أقفل الكتاب - اجلس - اكتبو ا ـ امسح السبورة - افتح الثبالك Tetapi juga kegiatan-kegiatan yang berlaku di luar kelas yang dapat didemonstrasikan, seperti: تبكي فاطمة - يضحك فريد - السائق يقود السيارة - الخادم يكنس البلاط

4) Latihan mendengarkan dan mamahami

Pada akhirnya, mendengarkan sesuatu adalah untuk memperoleh informasi. Infofmasi itu mungkin tersurat/ekplisit, dinyatakan seeafa jelas. Tetapi mungfcin juga tersirat/implisit, yang memerlukan pengamatan dan penilaian lebih jauh.

Untuk mendapatkan informasi yang akurat, dalam arti tepat dan bermanfaat, seorang penyimak harus pandai-pandai memilih dan mengingat hiana yang penting dan mengabaikan apa yang tidak penting, kemudian mengambil kesimpulan.

Ini berarti bahwa menyimak adalah ketrampilan yang dapat dicapai hanya dehgan latihan-latihan. Tujuan latihan menyimak pada tahap ini ialah agar siswa memiliki ketrampilan memahami isi suatu teks lisan dan mampu secara kritis menangkap isi 
yang dikandungnya, baik yang tersurat maupun yang tersirat.

Mereka diminta menyimak, memahami dan kemudian menjawab pertanyaan-pertanyaan yang telah disiapkan sebelumnya untuk menguji pemahaman mereka. Dalam hubungan dengan latihan mendengarkan untuk pemahaman ini perlu diperhatikan hal-hal berikut:

- Pendengar menerima informasi melalui rangkaian bunyi bahasa dengan susunan nada dan tekanan penempatan persendian (juncture). Perubahan susunan unsur bunyi dapat mengubah hubungan antarbagian kalimat atau arti kalimat secara keseluruhan. Kita sering menjumpai kalimat tanya yang bentuk dan susuman katanya sama dengan kalimat berita, namun berbeda karena lagu kalimat yang dipakai Dalam pelajaran menyimak henclaknya dipupuk kemampuan siswa untuk menafsirkan makna kalimat melalui unsur-unsur bunyi.

- Dalam tutur pembicaraan atau dalam teks yang dilisankan, biasanya terdapat gagasan pokok dan gagasan penunjang. Siswa hendaknya dilatih untuk dapat membedakan gagasan pokok dari gagasan sampingan, contoh dan ilustrasi. Misalnya dengan mengamati ungkapan petunjuk لأن, لذلك, رغم:peralihan, seperti dalam Bahasa Arab dan sebagainya.

- Dalam memilih teks lisan hendaknya guru memperhatikan hal- hal berikut:

- usia dan minat siswa

- kosakata yang dimiliki siswa

- tingkat kematangan dan kecepatan siswa dalam mengikuti teks lisan. Prinsip pengajaran: dari yang mudah ke yang sulit, dari yang pendek ke yang panjang, dari yang kongkrit ke yang abstrak, sebaiknya dipakai dalam hubungan ini.

- Kecepatan yang wajar tentu merupakan tujuan akhir pelajaran menyimak ini, tetapi untuk tahaptahap permulaan tidak ada salahnya kalau ucapan diperlambat sedikit. Yang diperlambat bukan ucapan kata-katanya, tapi jedahnya yang diperpanjang. Penyajian teks lisan untuk tingkattingkat permulaan perlu diulang, kalau perlu sampai tiga kali.

- Penggunaan alat peraga banyak sekali manfatnya dan dapat membantu mempercepat pengertian. Tapi ada kalanya alat peraga ini dengan sengaja tidak dipakai agar siswa tidak terlalu banyak menggantungkan diri pada isyarat yang diperolehnya dari alat peraga ini. Dengan kata lain, para siswa diharapkan memahami teks-teks lisan hanya dari isyarat yang diterimanya melalui gerbang telinga saja.

- Untuk tingkat lanjut, situasi perlu dibuat mendekati situasi sehari-hari. Gangguan- gangguan seperti background musik atau suara orang lain yang sedang bercakap-cakap, perlu dengan sengaja dimasukkan dalam rekaman. Hal ini tentu memersulit usaha meinahami teks lisan yatig sedang disajikan, tapi itulah realitas dalam kehidupan sehari-hari.

- Guru sebaiknya menuliskan kata-kata kunci sebelum pelajaran dimulai dan menjelaskan maknanya. Tentu saja tidak semua kata baru dapat dikatakan sebagai kata kunci dan dijelaskan kepada siswa, karena kesempatan untuk menerka arti kata dari hubungan kalimat perlu juga diberikan kepada mereka.

- Guru hendaknya menyampaikan kepada siswa dengan jelas apa yang harus mereka kerjakan. Petunjuk yang jelas akan merangsang para siswa dan menambah semangat mereka untuk berusaha memahami teks lisan yang disajikan guru.

- Untuk mengetahui sejauh mana pemahaman siswa terhadap apa yang didengarkannya, maka setiap materi yang disajikan hendaknya dilengkapi dengan pertanyaan-pertanyaan. Sistematika pertanyaan untuk pelajaran menyimak ini akan diuraikan kemudian.

- Respon atau jawaban para siswa bisa bervariasi. Untuk tingkat-tingkat permulaan, jawaban bisa berupa: gambar-gambar, atau jawaban lisan dengan bahasa Indonesia. Untuk siswa tingkat menengah atau lanjutan, jawaban dalam bentuk lisan atau tulisan dengan Bahasa Arab. Tapi perlu digarisbawahi bahwa tujuan utama bukan hakekat jawaban itu sendiri, tetapi pengertian yang ditunjukkan siswa terhadap teks lisan yang disajikan.

\section{Strategi pembelajaran Istima' modern}

Pada umumnya, pembelajaran istima' disampaikan dengan menggunakan media audio. Hal ini dikarenakan untuk mendatangkan natiq ashli tidaklah mudah, sementara itu jika dilakukan oleh guru langsung yang notabene bukan orang Arab asli, biasanya ada perbedaan logat dengan bahasa aslinya. Media audio yang biasa digunakan adalah tape recorder, CD, dan laboratorium bahasa. Hanya saja, jika dilihat dari pertimbangan efisiensi, maka tape recorder dan CD merupakan pilihan media yang cukup murah dan efektif digunakan. Dalam tulisan ini, akan dijelaskan 3 macam strategi pembelajaran istima' dengan menggunakan media audio tape recorder atau CD.

Beberapa strategi yang dapat dikembangkan dalam pembelajaran istima' ini adalah:

1. Strategi 1

Strategi ini bertujuan untuk melatih kemampuan mendengarkan bacaan dan memahami isi bacaannya secara global. Dalam 
strategi ini yang dibutuhkan adalah rekaman bacaan dan potongan-potongan teks yang terkait dengan isi bacaan tersebut untuk dibagikan kepada siswa. Langkah-langkahnya adalah:

Perdengarkan bacaan atau nash lewat kaset atau CD dan para siswa ditugaskan untuk menangkap isi bacaan secara umum. Setelah bacaan selesai, para siswa diminta membaca pernyataan-pernyataan yang telah dibagikan, kemudian memberikan jawaban benar atau salah terhadap pernyataan tersebut. Jika pernyataan tersebut sesuai dengan isi bacaan yang didengar, berarti benar, dan jika tidak sesuai maka jawabannya salah.

Mintalah masing-masing siswa untuk menyampaikan jawabannya.

Perdengarkan sekali lagi kaset tersebut agar masing-masing siswa dapat mencocokkan kembali jawaban yang telah di tulis Berikanlah klarifikasi terhadap semua jawaban tersebut agar semua siswa mengetahui kebenaran dari jawaban mereka masing-masing.

2. Strategi 2

Strategi ini lebih menekankan pada aspek kemampuan memahami isi bacaan dan menjawab pertanyaan-pertanyaan yang mengiringi dalam setiap bacaan tersebut. Langkah-langkahnya adalah:

- Perdengarkan nash yang sudah direkam dalam kaset maupun CD.

- Mintalah semua siswa untuk mendengarkan dan mencatat hal-hal yang penting

- Mintalah semua siswa untuk menjawab soal-soal yang disampaikan pada akhir bacaan tersebut. Jawaban dapat disampaikan secara lisan maupun tertulis

- Mintalah masing-masing siswa untuk menyampaikan jawabannya (presentasi)

- Berikan klarifikasi di akhir sessi terhadap jawaban siswa.

\section{Strategi 3}

Strategi ini tidak hanya menitik beratkan pada aspek kemampuan memahami isi bacaan, tetapi juga kemampuan untuk mengungkapkan kembali apa yang sudah didengarnya dengan bahasa sendiri. Langkah-langkahnya adalah:

- Perdengarkan nash yang sudah direkam dalam kaset atau CD.

- Tugaskan kepada setiap siswa untuk mencatat kata-kata kuncinya (keyword) sambil mendengarka.

- Setelah selesai, para siswa diminta untuk mengungkapkan kembali isi bacaan tersebut dalam bentuk lisan atau tulisan.

- Mintalah setiap siswa untuk menyampaikan (mempresentasikan) hasilnya secara bergantian.
- Berikan klarifikasi terhadap hasil kerja siswa untuk memberikan penguatan terhadap pemahaman siswa

\section{CONTOH DESAIN MATERI AJAR}

1) Standar kompetensi menyimak / istima'

(Memahami wacana lisan melalui kegiatan mendengarkan baik berbentuk gagasan ataupun dialog sederhana tentang النعارف).

2) Kompetensi Dasar

Menemukan informasi umum dan atau rinci dari berbagai bentuk wacana lisan sederhana yang meliputi kata sapaan (إلقاء التحيات), kata ganti tunggal (اسم الضمير للمفرد) , kata tunjuk (اسم) (اسم) dan kata depan (الإدوات الجر) dan kata sifat (النعت termasuk warna

3) Indikator

- Mengidentifikasi makna-makna/ arti dari kata-kata / kalimat yang telah didengar

- Mengartikan kalimat-kalimat dengan tepat dan benar

4) Tujuan Pembelajaran

Mampu bercerita/mengungkapkan isi materi

5) Materi Pembelajaran

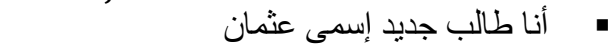

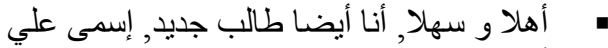

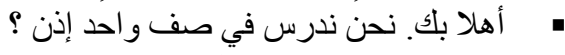



$$
\begin{aligned}
& \text { • على فكرة, هل أنت أخو الأستاذ شها, مدرس اللغة العربية ؟ } \\
& \text { " تعم , أنا اخوه }
\end{aligned}
$$

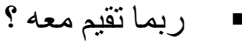

$$
\begin{aligned}
& \text { - } \\
& \text { • }
\end{aligned}
$$

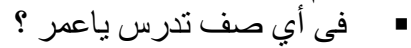

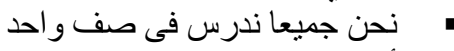

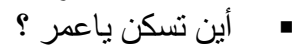

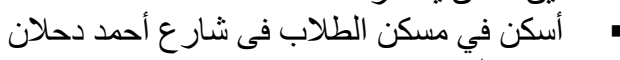

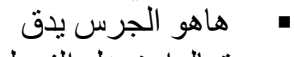

$$
\begin{aligned}
& \text { ت تعالو ا, ندخل الفصل }
\end{aligned}
$$

6) Metode Pembelajaran

- Ceramah : Metode ini digunakan untuk memulai kegiatan pembelajaran terutama untuk kegiatan awal.

- Kerja kelompok: kegiatan ini digunakan untuk mengumpulkan informasi التعارف

- Diskusi : Metode ini digunakan untuk mendialogkan tema yang berkenaan dengan materi kegiatan pembelajaran

- Pameran: pajangan hasil diskusi/kerja kelompok dan saling mengomentari pajangan

7) Langkah-Langkah Pembelajaran

\begin{tabular}{|l|c|}
\hline \multicolumn{1}{|c|}{ Kegiatan } & Waktu \\
\hline Pendahuluan : & 10 \\
Apersepsi dan Motivasi : & \\
- Menanyakan kepada siswa tentang & \\
\hline
\end{tabular}




\begin{tabular}{|c|c|c|}
\hline & $\begin{array}{l}\text { - Menjelaskan tujuan pembelajaran } \\
\text { dan manfaatnya dalam kehidupan } \\
\text { Kegiatan inti } \\
\text { - Siswa beradu cepat memasangkan } \\
\text { kalimat acak tentang التعارف التعارف (Eksplorasi) } \\
\text { (eksplorasi) } \\
\text { - Siswa membaca berbagai sumber } \\
\text { tentang التعارف } \\
\text { - Siswa saling menilai hasil } \\
\text { pemasangan berdasarkan apa } \\
\text { yang telah dibaca tentang } \\
\text { (Elaborasi) } \\
\text { - Siswa bertanya jawab dengan } \\
\text { guru tentang hal-hal yang masih } \\
\text { belum jelas (elaborasi) } \\
\text { - Guru memberikan penguatan } \\
\text { tentang kesimpulan فعارف) } \\
\text { (Konfirmasi) } \\
\text { Kegiatan penutup. } \\
\text { - Guru melaksanakan penilaian lisan } \\
\text { - Memberikan tugas pengayaan }\end{array}$ & $\begin{array}{c}10 \\
5\end{array}$ \\
\hline
\end{tabular}

8) Sumber Pembelajaran

- Hidayat, Pelajaran Bahasa Arab Untuk Kelas 1 Madrasah Aliyah, Toha Putra, Semarang 1994

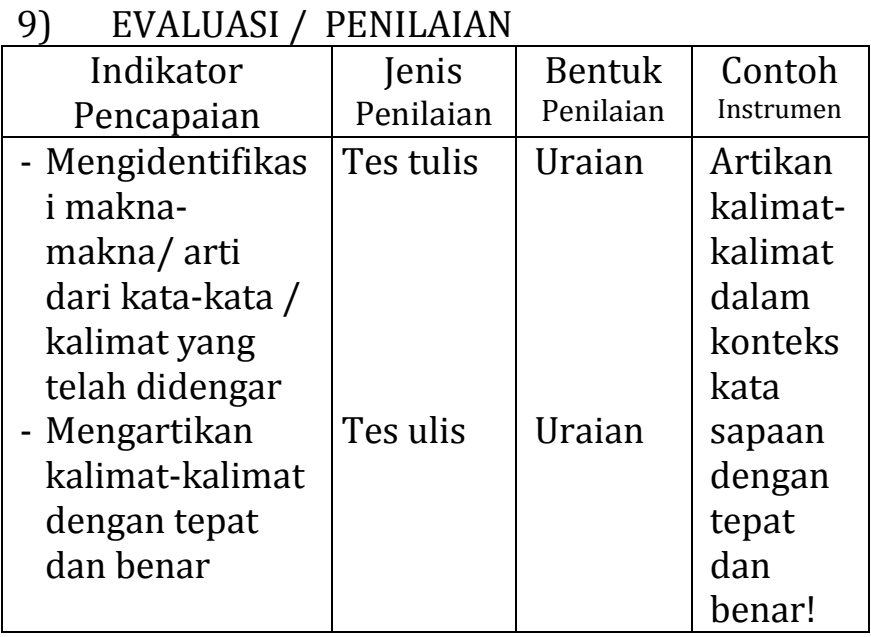

\section{DAFTAR RUJUKAN}

Acep Hermawan, Metodelogi Pembelajaran Bahasa Arab, Rosda Karya, 2011, Bandung.

Fuad Effendi, Metodelogi Pembelajaran Bahasa Arab, Misykat Amalng, 2012, Malang.

Ayip Rosidy, Pembelajaran Bahasa Arab Untuk Pemula/ Mubtadi, Metode, Materi, Strategi Dan Media, Kurnia Kalam Semesta, Yogyakarta, 2010

Iskandar Wasid dan Dadang Sunandar, Strategi Pembelajaran Bahasa, Bandung; PT Remaja Rosdakarya 2010.

Mappanyompa, Husnan: (2019) Pengaruh Pendidikan Kemuhammadiyahan Terhadap Sikap Perilaku Siswa, 4 (1) 17-29.
Muhibbin Syah, Psikologi Pendidikan, (Bandung, Remaja Rosdakarya, 2014)

Nana Sujana \& Ahmad Rivai, Media pembelajaran, (Bandung: Sinar Baru Algesindo, 2010)

Nyayu Khodijah, Psikologi Pendidikan, (Jakarta: Rajagrafindo Persada, 2014)

Fatchul Mu'in, Pendidikan Karakter Konstruksi Teorotik \& Praktik, (Jogjakarta: Ar-Ruzz Media,2016),

Jamal Ma'mur Asmani, Buku Panduan Internalisasi Pendidikan Karakter Di Sekolah, (Jogjakarta: Diva Press,2011)

Sukarjo dan Ukim komarudin, Landasan pendidikan konsep dan aplikasinya, ( Jakarta: Rajawali Pers, 2013),

Masnur Muslich, Pendidikan Karakter: Menjawab Tantangan Krisis Dimensional, (Jakarta: Bumi Aksara, 2014). 